\title{
The Imperial Policies in Land Reform and the Conditions of Peasants in Highland Gimbi, Western Wallaga, Ethiopia (1941- 974): Historical Perspective
}

\author{
Bijiga Gerba \\ Department of History and Heritage Management, College of Social Sciences and Humanities, MaddaWalabu \\ University, Bale Robe, Oromia, Ethiopia
}

\begin{abstract}
Land has been an economic and political basis in the history of Ethiopia. The feudal governments since the time of Minilik II measured, confiscated and redistributed land to those politically important individuals. The objective of this study is to assess the imperial policies in land reform and the conditions of peasants in highland Gimbi, Western Wallaga from 1941 to 1974 . This study has used both primary and secondary sources to examine the imperial government land reform and the conditions of peasants in highland Gimbi from 1941 to 1974. Archival sources from Wolde-Mesqal Archival center at the Institute of Ethiopian Studies, Addis Ababa University, and oral sources ${ }^{1}$ collected through in-depth interview are extremely important in this regard. Under the imperial government in post-liberation period, land reform and its grants to officials and others concentrated land in few hands whereas the number of the landless peasants highly increased. Even though, the 1952 imperial order theoretically enabled the landless farmers to get half gasha of land, in Gimbi no grant was made to the landless peasants. Land privatization was aggravated under the restored government. Above all, with the intensification of coffee cultivation, in highland Gimbi the price of land was exacerbated to the extent that only the well-to-do class members were able to buy land at the expense of the majority of the peasants. Overall, the study of the imperial policies in land reform and its impacts on the population at the grassroot level enable us to have a better historical perspective towards land tenure system and the peasants whose livelihood directly tied to it.
\end{abstract}

Keywords -Land tenure, land reform, land measurement, landless peasants, Gimbi

DOI: $10.7176 / \mathrm{HRL} / 52-03$

Publication date: December $31^{\text {st }} 2020$

\section{Historical Background}

Prior to the incorporation of Wallaga, in which Gimbi is part, into the Ethiopian Empire in the close of nineteenth century, the peasants had full ownership rights over extensive land which was transmitted collectively from generation to generation. Even at the initial stage of the incorporation peasants had an ownership rights to their land though the products of the land were appropriated by the ruling class. It is obvious that since land was the economic basis in the Ethiopian empire limiting the size of the land for sale or redistribution was very critical for the government of Minilik II and his associates.In line with, the 1910 land measurement act introduced a new form of land tenure known as qalad system which officially classified land into three categories of fertile, semifertile and unfertile. A number of factors can be taken into consideration the motive behind the introduction of qalad system. One of the major motives behind land measurement was to identify land for sale to generate government revenue and allocate the rest of the land to soldiers as maderia, and officials in lieu of salary [1]

It is evident that the process of land measurement and its confiscation and redistribution in Gimbi was undertaken during the governorship of Dejazmach Kumsa (1889-1923), the son and successor of Moroda. When the new proclamation was set out for implementation the peasants were asked to identify the land on which they claimed full ownership rights and the land was measured into gasha. Upon land measurement, the peasants remained with one-fourth which was locally known as siso, and the rest three-fourth was confiscated by the government[1][2]

It should be noted here that during land measurement and its redistribution, the local peasants misunderstood the term siso which the government of Minilik employed simply to indicate together with the church and the feudal hierarchy superimposed on them. The peasant, however, misunderstood as if the land would be divided into three equal parts only, and they would be left a siso, that is one third of the land they had occupied. Nevertheless, the government of Minilik II did not intend the land into three equal parts, but instead vast tracts, declare them state land, make them ready for sale for anyone with his ready cash at hand[1]

The event had far reaching consequences on the lives of the majority of the rural population. The 1910 land measurement reduced majority of the peasants Wallaga at large and Gimbi in particular to the status of tenancy. When land was measured the original inhabitants were given possession rights of small portion of the land they

${ }^{1}$ Informants were willing to share their views on the issues they were interviewed, but some asked for confidentiality of their identities. So, instead of mentioning their name the researcher prefer to indicate them by number in reference 
had previously occupied. The government confiscated three-fourth of the land from the local people leaving only one-fourth. When the newly confiscated land granted or sold to individuals the same peasants became the tenants of the new grantees of purchaser. Following land measurement in Gimbi, the church had also exclusive rights of receiving the land confiscated from the peasants. When land was measured, samonland was given to the people who served the church. The peasants who lived on such land had no claim on the land. Apparently, they had to serve the church officials by paying tribute and tithe to the owners of church land. Otherwise, the owners of the land could evict them whenever they unable to pay obligations government [1]

Another motive behind land measurement rested on tax to be paid. Tesema explains this in such way: "...the other important objective of land measurement was to systematize and regularize taxation in the country and to ensure that taxes were paid by all people." Taxes were imposed on all types of land except church land. Land held by church was tax exempted. The land classified as fertile, semi-fertile and unfertile eased not only the process of land selling and buying but also helped to levy tax on the peasants based on each category of land. On this basis the government imposed a tax of 15 Thalers for fertile land, 10 for semi-fertile and 7 for non-fertile land.For majority of the peasants the rate of taxation proved to be heavy and as such the peasants unable to pay taxes were forced to abandon their claims [1]. The government confiscated this land under the title gebertel.

In general, in Gimbi the living conditions of the peasants were negatively affected by the land confiscation, and redistribution and fragmentation caused by land measurement. While the lucky groups were granted to large tracts of land, most of the indigenous rural population was left to siso. When land was measured the officials even abused their power and assigned the best land to the state whereas the land allocated to clan chiefs by and large was 'unfit for agriculture'[3] . Above all, for those who paid tax and tribute that small portion of land was fragmented year after year among the descendants of the owners [4]

During the Italian occupation (1936-1941), the peasants became happy with the Italians because they got back their land. But at same time they were under burden of paying tribute and back breaking labour services rendering to the Italians. Upon the expulsion of the Italians from the country in 1941, the monarch restored and the process of land reform, imposition of taxation and the subsequent tenancy problems aggravated.

\section{Government attempts at Land Reform (1941-1974)}

Right after the Italian Evacuation from Ethiopia, Emperor Haile Sellase pursued the old land granting policy and at the same time made an attempt to solve land related problems. In 1941, the restored emperor issued a proclamation in which he openly outlawed the gabbar system. The feudal dues such as manual labour, firewood, grass contribution for annual feast days and miscellaneous dues and were abolished[5]. This, however, seems to have made to minimize the burden on small scale owner cultivators (gabbars) who were subjected to give both tribute and personal services to government officials. Government officials were to be paid monthly salaries by the state. It is apparent that it had brought no change on the life of landless peasants (tenants) who had remained to be exploited by their landlords until the demise of the imperial government in 1974.

It has been the usual trend to overlook the peasants whose livelihood was directly tied to land. Emperor Haile Sellase's land granting policy rested on those politically important individuals and groups. In other words, the policy of granting land was not based on economic development, but political orientation. "Priority will be given to those who have served the government for a considerable time in battle or in other ways"[5]. The emperor unduly tended to give due emphasis them because they had served the government either prior to the Italian Invasion or throughout the occupation period. Emperor Haile Sellase's land granting policy devoted much attention to the privileged classes not only for the meritorious services they had contributed but it also considered security issues in the post-liberation period. In the history of Ethiopia, land used to be the means by which the rulers had maintained the loyalty of the local governors to the central government. Like predecessors, the restored emperor had to reactivated the old fashioned land granting policy to keep the allegiance of and faithfulness of the military forces and government officials at different levels of state hierarchy [6].

To implement land granting policy, successive imperial orders were passed. They July 1942 and 1944 were the early imperial orders in post-liberation period. The 1942 granted soldiers who were involved the liberation struggle one gasha of land. The 1944 imperial decree entitled the pre-war soldiers and civil servants to a free hold of one gasha of land. This order was later amended several times to include and grant armed forces, air force, police and civil servants land as a reward for their services and loyalty[7] [8] . Post liberation Gimbi experienced such grants of land as it was elsewhere in southern provinces. There were a number of soldiers who made the long march to Maichew from Gimbito fightthe Italian invaders. Government lands in highland Gimbi were given to Soldiers as maderia and which was granted to civil servants, high ranking officials and the like for their services and loyalty.

The newly restored government made an attempt to improve the life of tenants in 1952 . The November 3, 1952 imperial order promised the landless peasants and unemployed Ethiopians half gasha of land. Specifically, the landless peasants who lived on the government land were promised to be entitled to the same land they worked on [9]. It is questionable as to how much of the landless peasants really benefited from this order at the 
countrywide level. A close investigation of the 1952 imperial order in Gimbi Awraja, however, indicates that it did not serve the purpose it was meant for. Archival sources researcher has come across vis a vis Gimbi Awraja show that it was rather non-farming individuals who enjoyed the provisions of the 1952 order [10]

It is worthwhile here to note that the application process for land was very difficult and inconceivable for landless peasants to get half gasha of land. The bureaucracy associated with land requesting procedure at different levels of government offices was prohibitive. The process commenced at a warada administrative level. Any applicant for land had to appeal to the warada office for certificate which shows that the individuals were really landless and unemployed. In case the applicant was able to convince the warada officials about his current status of landlessness and being unemployed they certified him that he was qualified to apply for land. Then after, the lower office began to communicate the case to the upper strata of hierarchy tied up to Ministry of Interior. It was from here, that is the land registration department section of the Ministry that an approval letter would be sent through a proper channel down the warada office from where an order would pass down to the Abba Qoro of the area where land was said to be available. This result, however, was in vain in most cases [6]

It is quite clear that the landless and unemployed had to go through a lengthy and costly process of claiming and getting half gasha of land. The process requested a lot of bribing and time. In this regard, they had to wage a long and extensive struggle against the bureaucracy. Many of them were frustrated by the lateness across the state hierarchy and were compelled to withdraw their application while others did not want to apply at all for they had understood that they could hardly afford [10]

In 1963, after a decade of issuing the 1952 imperial order theoretically favored landless and unemployed, Emperor Haile Sellase made his visit to Gimbi Awraja, specifically, Yubdo Warada which was well endowed with gold and platinum minerals. The information that the emperor was about to visit the gold and platinum area of Yubdo was spread in different parts of Gimbia wraja and the neighbouring awraja like Qellem. Land tenure and related problems teamed up tenants from different waradas with one another to appeal their common problems to Emperor Haile Sellase. Holding a letter of application in their hands the tenants gathered in Yubdo to meet the emperor. In this letter of application, the crowd pointed out that they could not get half gashaof land according to the provisions of the 1952 order because of the futile exercise associated with the application process for land. In other words, they requested the emperor the promise of the order to be genuinely fulfilled. Above all, the landless peasants came out their homes with a drama which they thought that it could convince Haile Sellase to understand their living conditions actually look like in the society. Many of them joined the gathering being under yokes in pair, while other carried on their heads broken ceramics which contained dry cow dung set on fire. Emperor Haile Sellase visited not only the mineral area but also the drama performed by the wretched tenants on their real life [11]

This tour provided the emperor with the opportunity to observe the living conditions of the landless peasants who hand remained to be the beast of burden and whose life smouldered by the exorbitant exploitation in the form of rent as well as free labour services. That is why the tenants tried their best to convince the emperor practically about their present conditions of life in addition the letter of application. They did this intentionally anticipating that the emperor would bring changes to the situation which became insurmountable obstacle to get access to land, and then, they would be granted to it which would help them to be free from someone exploitation. It is reasonable to think that the emperor grasped how serious the problem was. To their surprise and dismay, he responded nothing to their applications [12]

Both secondary and archival sources unanimously supported local oral sources. By comparing and contrasting the prevalence of tenancy in twelve provinces in Ethiopia, Bezuwork has come up with the reality of the 1952 imperial order in highland Gimbi based on the letter of application in the Ministry of Agriculture he had come across. He stated that a deputy from Gimbi Awraja representing landless peasants wrote a letter to the president of the House of Deputies on February 3, 1968 complaining that the government officials using their good offices abused the 1952 imperial order. "When these individuals began the process, the officials acted as agents of the grantee and finally bought the land for themselves" [13]. This imperial order was meant only for landless and unemployed. However, these poor and landless groups of individuals were treated without favour by the local government officials who sealed their loss of chance of holding land in such circumstance.

The government of Emperor Haile Sellase failed to give attention to the economic hardships the peasants were severely suffering due to shortage of accessible agricultural land. In fact, his government had once already passed a proclamation in favor of the poor and landless. Nevertheless, there must be strong will and determination to put what was legally established into practice. Had, this order been genuine, the landless peasants in the country at large and in Gimbi in particular could have benefited. However, it had no practical value.

Archives in the WoldeMeskal Archival Memorial Center (WMAMC) which has been under the custody of Institute of Ethiopian Studies are full of letters of applications. Such letters of applications were submitted either directly to the emperor or the Ministry of Interior and the latter Ministry of Land Reform and Administration. The applicants were either the landless tenants themselves who demanded half gasha of land in accordance with 
the provisions of 1952 imperial order or the parliamentarians who observed the problems in their respective constituencies. Generally, almost all of these letters of applications from the deputy submitted to the concerned quarters exposing the problems of landless peasants while the crisis was mounting on the eve of the 1974 Revolution. Whatever the hidden motive would be behind the exposure most of what was stated in these letters of applications are of paramount importance for historical reconstruction. They shed lights on the position of landless peasants, the process of land confiscation and alienation which reduced the appellants to their present status of landlessness. This in turn reflected the change in land tenure, the evolution of agrarian society and in landlord-tenant relations.

As has been discussed landless peasants could not get benefit from what was theoretically meant for them. The feudal government of Haile Sellase gave support to improve the life of landless peasants in the absence of its practicability. In other words, there was no determination and will on the side of the government to implement the 1952 order. This order remained tantalizing the heart and minds of the tenants without becoming real. In the process the 1952 order served the purpose it was not meant for. It was government officials and other nonfarming individuals who were privileged by the 1952 order. Archival sources indicate that the accumulation of land in the hands of government officials and others. In fact, these groups of individuals were rushing to accumulate land as much as they could. Different mechanisms of accumulating land were used. One of these mechanisms used particularly by the government was using political Positions Another means of acquisition of land was through government land grants. Furthermore, the process known as registering gibretelmaret helped the local government officials to acquire land on one hand extremely affected the peasants on the other. This was the land taken over by then government on the pretext of the peasant's failure to pay tax. It is apparent that in case small owner cultivators were unable to pay taxes the government automatically registered the land as government property. In fact, it was one of the sources from which the government accumulated land for future grants or sale[14]

\section{Landlord-Tenant Relationship in Highland Gimbi}

As already discussed earlier, tenancy in Gimbi had its origin in Minilik's conquest. Internal socio-economic and political dynamics had no brought the appearance of private property in land. It was after the land measurement act of 1910 that private ownership of land and the concomitant tenancy developed. Above all, it was after the restoration of the monarch in 1941 that privatization of land and the consequent increase in tenancy became high. Whatever the means of confiscation either through government grants or personal efforts of gaining land most of the beneficiaries became wealthy at the expense of the peasant majority. The process of confiscation and alienation facilitated the concentration of land in the hands of few whereas the number of landless peasants highly increased, that is less landlords to landless masses correspondence in highland Gimbi[13] and [14].

According to a report on land tenure in Wallaga Province in 1967, most of the landlords lived on their holdings while few of them were absentees. Some of the big absentee landlords were the descendants of Leqa Oromo rulers. Absentee landlords lived mainly in capital cities like Addis Ababa and Naqamte, the capital of Wallaga province and they visited their land mainly during the harvest season to collect what was due to them [15]

The tenants lived in miserable conditions of life. They hand to hand over the lion's share of their gross produce to their land. The tenants were required to pay parts of their produce which was locally known as erbo. The word erbo originated from the Amharic term irub which means one-fourth. In fact, this term was nominally used in Gimbi Awraja. In case some landlords became lenient to a few tenants were expected to pay one-fourth of their harvest. Otherwise, the overwhelming majority of the tenants were forced to pay part of their produce varying from one-third to half or fifty-fifty basis. Being the main cash crop, coffee harvest was shared between the landlords and tenants equally. This was so particularly in the 1950s and 1960s when land came to be seen as precious commodity with the rising price [16].

On the other hand, in most cases, the landlord did not provide oxen where as the most widely practiced tenancy agreement was share cropping. This meant that the tenants had to provide their own oxen. It is evident that the peasant at large did not own oxen while they were accumulated by landlords, civil servants and merchants. Since oxen have been used as the most important and indispensable kinds of farm implements the tenants had to rent them from the aforementioned classes. This brings us to say that rent of oxen was another form of tenants' exploitation by their landlords [6].

It is interesting to note here that most of the agreements between the landlords and tenants were not effectively operated by written statements. It was rather reached on verbally. But verbal agreement was usually disregarded if the landlords disheartened [17].

Moreover, the tenants were obliged to render free labour services to their landlords. It is commonly true that free labour services were uniformly practiced in Gimbi. Despite the 1944 land tax proclamation which has prohibited free labour services and ruled 'taxes, services and fees' to be paid in cash, the tenants continued to give free labour services to their landlords. These services were the implicit obligations expected from the 
tenants inculcated as personal rights in the minds of the landlords. In case any tenant refused to perform compulsory labour services the landlord could rid of him mercilessly and replace him with a new tenant, to avoid such eviction, therefore, it was up to the tenants to fulfill the required obligation to their lords. The tenants on church land (samon) were also required to pay tithe and tribute to the church. Occasionally they were required to perform labour services such as construction of churches and repairing fences[18].

The existing regulation on which landlord-tenant relation was framed had nothing to with the wellbeing of the latter other than supporting and fulfilling the interests of the former. For instance, the high rate of exploitation and arbitrary eviction of the tenants exercised by their landlords, which became absolute in the last fifteen years of the imperial rule could be considered as the weakness of the 1960 Civil Code. This could did not limit or put the exact contract time. It was, therefore, the tenants that could be exposed to arbitrarily eviction which the landlords would exercise at their will [7].

In the mid-1960s and early 1970s the Ethiopian government was busy to preparing tenancy bills at least to amend the 1960 civil code. The motive behind these bills might have been the imperial concern for economic and social development based on modern ways of agricultural production by exploiting external aid and donating organizations. Hence, improving the present landlord -tenant relation seems to have been critical in the mind of Emperor Haile Selasse. The tenancy bills was devoted to relief tenancy problems and aimed at reducing the maximum rent, avoiding arbitrary eviction, fixing contract time and prohibiting free labour services. In other words, the bills gave due emphasis to improve landlord-tenant relations so as to enable the latter feel secured from high rent, free labour services and arbitrary eviction and engage themselves in surplus production. The bills did not focus on the plausible land ownership and land distribution questions[13].

It would be futile to bring economic and social progress considering agriculture as the backbone of development in the presence of insecurity of land tenure. Majority of peasant population were far from the opportunity to possess their own land under the antiquated form of land tenure system whereas few individuals who did not toil on the land except clutching what their tenants produced. The remoteness of many peasants from owning land privately remained to be the fundamental obstacle to the agricultural progress in the country. The remoteness of many peasants from owning land privately remained to be fundamental obstacle to the agricultural progress in the Country [7].

It is undeniable the land reform was indispensable to agricultural development. The investigation made by the Ministry of Land Reform and Administration in ten provinces, after creation on October 1961, attributed Ethiopia's agricultural setback to the existing archaic land tenure system. According this investigation, the preponderant number of tenants under share cropping became an impediment to surplus production and thereby agricultural progress. From the field investigation, therefore, the Ministry concluded that reforming the present unfair land tenure had paramount importance in bringing agricultural progress in the country [13].

Besides, the Third Five Years Plan had equally revealed the insecurity of land tenure was the major reason for economic backwardness underlined the great importance of reforming this land tenure in bringing about economic development [13] . However, there was no strong movement on the part of the government to bring changes in the present land tenure. Had land tenure been reformed agricultural underdevelopment in general and tenancy problem in particular would have improved. This might have brought economic and social development for which the then government was ambitious having nebulous position. Above all, the tenancy bills prepared on the tenancy problems as its focal point on improving landlord-tenant relations remained to be the mere point of discussions among the parliamentarians in the two chambers without becoming real. Most of the members of the Ethiopian parliament were the conservative forces who were rushing to exploit everything to their advantages. They could not see the miserable position of the tenants by overcoming selfishness attitude they had familiarized with. The bills rather seem to have helped the Ethiopian government to get aid from foreign donating organizations. Many segments of peasant's population in Ethiopia at large and Gimbi in particular remained to face economic hardships [19].

\section{Land, coffee Cultivation and the Condition of Peasants}

As has been seen government officials and non-farming individuals managed to accumulate land while majority of the peasants remained to be landless. After accumulating gashas of land the government officials began to sell the land to the individuals who wanted to invest their money in coffee cultivation. Highland Gimbi became an important coffee producing region in Ethiopia [20].It is said that the widespread of coffee cultivation contributed an immense increase in the price of land. A gasha of land classified as infertile cost birr 40 to 50 in the $1950 \mathrm{~s}$. It was very difficult for landless peasants to afford birr 40 to 50 to purchase land by themselves. In case the landless peasants could afford the money they had to compete with the bureaucrats, merchants and feudal lords. Government officials and merchants entered the lucrative business of buying and selling land for the well-to-do classes at the cost of the landless peasants. Land became a very commodity exchanged between the well-to-do classes. They benefited at the expense of the majority of the peasants [21].

The most important worth mentioning here is that the expansion of cash crop production had great 
repercussions on the landless peasants. In the process of buying and selling land, when an individual inspected the land they had bought and found tenants on the newly bought land, he used evict them automatically and turned the land into coffee production. For this reason, the tenants on such gashas of land lived in the state of tension and desperation and were always at disadvantage. Nevertheless, tenants on siso and church land did not encounter such difficulty. Relatively speaking, the tenants favored to live on the siso or church land rather than living on land for sale. Those tenants on the siso land were somewhat better than others. Eviction was unusual though it was not absolutely absent [18].

The tenants who were saved from eviction sympathetically did not escape the consequences that coffee cultivation as bringing. Due the cash crop orientation of the well-to-do classes the land that was formerly used by tenants to produce food crops began to be substituted by coffee trees. After sharing their grain harvests to the landlords, the tenants were left with very little amount of food crops. The rent along with the reduction in the production of food crops from time to time exposed majority of the peasants to starvation mainly during the rainy season[21].

The peasants' response to this seasonal food shortage was that they adopted coping strategies. One of these copping strategies was moving from highland areas to inhospitable lowland areas where land was relatively plentiful. The concentration of land ownership to a few individuals was high in highland Gimbi. At same time coffee cultivation was rapidly expanding in the highland region. Desperate and compelled by these ci circumstances the landless peasants decided to move down to the hostile lowlands seeking for agricultural land in the late 1960s. For instance, in the year 1967 alone, a number of tenants estimated to be more than one thousand represented by one man requested the Awraja Ministry of Interior Office to give them land in lowland Gimbi. This was when the Department of Ministry of Land Reform and Administration was on the way to be established which since 1968 administered land tenure system. However, such peasant movement was not supported by the newly established Ministry of Land Reform and Administration [22].

Another form of coping strategies that the peasants adopted to be relieved from acute food shortage was that they grew short time maturing root crops. These root crops were mainly qoco, potato and ancote. All of them are tuberous plants and were locally known as small foods. These root crops played a significant role in the summer season when grain crops such as maize, teff and the like were used up and thereby the peasants were extremely starved. However, they were not produced on large quantities due to mainly scarcity of land; the peasants consumed them for a short period of time [21].

Consequently, the peasants were compelled to borrow money at exorbitant interest rates usually from government employees, merchants and landlords. Though the peasants used the means of getting money as coping strategy, it was this practice that greatly affected the poor peasants. It is revealed that the overwhelming majority of the peasants had no possibility of getting loans from relatively to repay the money at the rate it would be borrowed was very rare. Thus, it is quite sure that majority of the peasants had to go usurers. In most cases, peasants borrowed birr ten for one farasula of dried coffee beans. To this effect, the agreement between the two parties (usurers and borrowers) was reached on written statements in the presence of eye witness. It is evident that the price of coffee increased from time to time whose victims were the peasants themselves [21].

On the other hand, increasing in the land values under the stimulus coffee cultivation exacerbated land litigation. The main causes for land litigation were disagreement between landlords and tenants, boundary problems and inheritance among the descendants of the siso holders. Land disputes were handled in warada, awraja and provincial offices. There were also instances, were court of appeals were taken to Addis Ababa where defendants or plaintiff could afford the money to sustain themselves and wanted to maintain the decision of their cases mad at provincial level. Some people directly went to the provincial or the emperor for cases which could be handled by the warada governors. The provincial governor or the emperor could decide nothing except the order of the warada to decide properly. Because of failure to get any decision the litigants were obliged to go back to the warada; the governor of the warada could not decide the case quickly but delayed because the case was directly taken to the governor of the province or the emperor. This led to wastages of money and time [6].

In general, the living standard of the majority of the peasant was descended. New form of land tenure system since the time of Minilik II severely depressed the economic wellbeing of most of the people in the conquered regions. Land became highly profitable for few individuals at the expense of the peasant majority. As things followed their own course, the contradiction between the landlords and the landless masses got worse. The multiple exactions imposed on the peasants during the Imperial period resulted in the appropriation of a considerable portion of the peasants' production, onerous labour services and other impositions. Given the low productivity of the peasants' production, the amount of taxes and tributes they paid represented heavy burden on them. It resulted poverty and starvation and consequently, lower standards of living. Partly, it was this gloomy conditions of the peasants resulted from inequitable land holding system that led to the 1974 Ethiopian Revolution under the slogan "Land to the Tillers". The Derg regime came to power in 1974 and passed land reform proclamation after a year which officially nationalized land and redistributed it to the farmers. 


\section{Acknowledgement}

I am very much indebted toSamara University whose financial support contributed towards the realization of this study. I am also thankful to the staffs of the visited WoldeMeskal Memorial Archival Center, district Culture and Tourism Office for their provision of important documents. I also wish to extend my deepest gratitude to all my informants.

\section{References}

[1] Tesema Ta'a. (1980). "The Oromo of Wallaga: A Historical Survey to 1910.” M.A Thesis, Addis Ababa University, Department of History

[2] Gutema Imana, (1987). "A Historical Survey of Land Tenure System in Aira Guliso Warada, Central Wollega c. 1880 to 1935." B.A Thesis, Addis Ababa University, Department of History

[3] TesemaTa'a, (1984). "The Basis for the Political Contradictions in Wollega: The Land Apportionment Act of 1910 and its Consequences", Northeast Africa Studies, Vol.6, No.1-2

[4] Hultin, Jan. (1982)."Kinship and Property in Oromo Culture.”S.Rubenson (eds), Proceeding of the Seventh International Conference of Ethiopian Studies, University of Lund

[5] Gebre-Wolde-Ingidaworq, (1962). “Ethiopia's Traditional System of Land Tenure and Taxation”. Ethiopian Observer, Vol.5. No.4

[6] Eshetu Chole, (1968). “ Taxation in Ethiopia: An Analysis of Structures, Policy and Performance” B.A Thesis in Economics, University of Illinois, Urbana

[7] Stahl, Michael, (1974). Ethiopian Political Contradictions in Agricultural Development, Stockholm: Uppsala University Press

[8] Cohen, M. and Weintraub,V. (1975). Land and Peasants in Imperial. Ethiopia: The Social Background to Revolution. Assen: Vagorcum

[9] The Ethiopian Herald (1952), No. 15,

[10] Informants: No. 11 and No. 27

[11] Informants: No. 3, No. 18 and No. 29

[12] Informants: No. 3, No. 18 and No. 29

[13] BizuworkZewde, 1992, "The Problem of Tenancy and Tenancy Bills with Particular Reference to Arsi" M.A Thesis, Addis Ababa University, Department of History

[14] Wolde Meskal Tariku Archival Center: Folder no.2178 File no. 2168, Addis Ababa, Ethiopia

[15] Ministry of Interior (1967): A Report on Land Tenure Survey of Wollega

[16] Hunduma Gudeta , (1969). “A Regional Study of Ayira”, H.S.I.U, Department of Geography

[17] Central Statistical Office, Survey of Wollega Province 1967).

[18] Informants: No. 5, No. 21 and No. 25

[19] GabruTareke. (1991). Ethiopia: Power and Protest: Peasant Revolt in the Twenty century. Cambridge University Press

[20] Hultin, J. (1987). The Long Journey: Essays on the History of descent and Land among the Macha Oromo. Uppsala University Press

[21] Daniel Ayana, 1986, "Coffee and Food Crop Production for Self-Sufficiency: The case of Western Wellega, An Outline" Proceedings of the Third Annual Seminar of the Department of History, Addis Ababa

[22] Wolde Meskal Tariku Archival Center: Folder no.34/86 File no. 61/5 Addis Ababa, Ethiopia 